\title{
DISASTROUS SITUATIONS AND POSSIBLE HYGIENE-EPIDEMIOLOGICAL PROBLEMS
}

\author{
Romanova H. \\ Medical University - Varna \\ Reviewed by: Assoc. Prof. Z. Zlatarov, MD, PhD
}

\begin{abstract}
The disastrous situations and hygiene-epidemiological possible problems were analyzed and their manifestation and role described. In case of the most frequently met disasters - earthquakes, floods, slides, fires, damages, epidemics, use of biological weapons and others, it is necessary that the medicative-evacuation and hygiene-epidemiological problems to be decided. Hygiene-epidemiological insurance have to have a leading role in case of floods, epidemics and bioterrorism. The role and the effectiveness of anti-epidemical activities in case of disastrous situations, with the exception of epidemic, are insufficient investigated.
\end{abstract}

Keywords: disaster, disastrous situations, hygiene-epidemiological problems

\section{INTRODUCTION}

According to World health Organization the disasters are as a result of natural phenomena or human activity and represent a threat to life and people's health and require a help by outside.

In foreign literature $(2,3)$ the generalization of all mass and suddenly appeared situations it's perceived with the concept "catastrophe". During the last years this concept is perceived and in Bulgaria like a synonym of disaster.

G. Abbado (1990(, R. Leonard (1991), P. Pepe (1991) define the disasters like a dangerous actions of natural forces or people that can't be overcome with local actions.

Incidents with many distressed people are defined like disasters and the arisen situation like "disastrous situation" In the mass of publications predominate mainly data for the place of disaster, number of perished and distressed people, organization by medical help and others. About the questions of hygiene - anti epidemiological insurance, the data are very scanty, even missing. This can be explained with the necessity of quick investigation and saving of distressed people.

As a result from the destructions caused by earthquakes, a hazardous hygiene - epidemic situation is found, -due to polluted area from damage drainage; difficulties in finding and pulling out corpses of dead people and animals. The above mentioned leads to the appearance or increase in number of rodents, insects and other carries of series of diseases of infectious and non-infectious origin, risk of abdominal typhus, paratyphoid A \& B, salmonellas, hepatitis, cholera etc. (9)

The damages caused by earthquakes are a result from destruction of buildings, fires, breaking of gas - mains, heating systems, drainage etc. $(9,10,11,12)$

\section{DISASTROUS SITUATIONS}

According to the data of authors like $(13,14)$ Bulgaria is divided into two - three main seismic regions. Risky seismic regions with Magnet 6,5,7 or more are Kresnenska, Plovdivska, Sofijska, Gorno Oiahovska and Shablenska.

The seismic analysis of Republic of Bulgaria shows that over $98 \%$ of its territory falls under 7 or higher degree in "MShK". Intensification of the seismic in the country has been registed in the last years and it is considered to be a precursor of strong earthquake. (15)

On the territory of the country approximately 100 earthquakes with slender magnitude are registered monthly. (16) According to the forecast estimates the territory of department Varna has magnitude (M) 7,1 - 7,5 in Richter, deepness - 20 kilometers, intensity 7,8 and 9 degree according to the scale of Medvedev, Shponheuer- Karnik.

The basic preventive medical undertakings in the dangerous seismic regions consist of training of giving first medical aid and organizing a sanitary, anti - epidemical actions. Censorious sanitary control is held for preventing an epidemic situation. (17)

The majority of authors $(18,19,20)$ think that earthquakes is a complex disaster. Besides the direct damages there are other secondary ones, that are not less dangerous and harmful - fires, epidemic outbreaks, landslides and so on that require applying of hygiene and preventing epidemic outbreaks cautions.Floods are usually natural disasters that cause the highest risk of rising hygiene - epidemiological problems. Floods come from heavy rains, fast melting of the snow, overflowed rivers etc. (21)

Loses caused by floods depend on their basic physical parameters - frequency, speed of water rising, duration of the flood. These parameters determine the holding of medical 
events and special hygiene - epidemiological precautions. (22)

The average annual number of floods in Bulgaria is 37 but in 1999 they are 157, in 2005 - 185. in case there is a flood, besides giving a medical aid for the victims and evacuating people from the flooded areas, the hygiene epidemiological actions are of big importance. The last predominant in number and crucial for people's health.(23)

Floods are actual danger for epidemic outbreaks, due to the polluted area from damaged drainage; difficulties in finding and pulling out corpses of dead people and animals. Of great importance are the precautions: holding a continuous sanitary control of water, food supplies; providing water supplies from other sources, throwing away of bad food or giving instructions for using it under appropriate heat treatment only. (24)

V. Dramova (1985), P. Payment (1991), B. Yustinianova (1993) think that if central drinking water supply is provided, the epidemiological risk of acute intestinal contagious diseases carried by water is less.The U. S. statistics points that landslides are third in the list as a reason for causing natural disasters which cause big material losses and victims. The distractive effect from landslides is equal to the losses from earthquakes. (28)

Dragging down of huge earthy masses and blocks of rocks bury under built-up areas, homes, transport infrastructure in various regions of the Earth and cause serious hygiene-epidemiological problems. (29)Forest fires could be a result of natural disasters - thunder strikes (2\%) and anthropogenic type - careless using of fire (98\%). (30)

Ts.Mihailov (1991), S. Trantner (1997) pay attention to the reduced qualities of soil, the pollution of air, water and soil which create prerequisites for disturbing the bio - balance with massive diffusion of pest insects; illness - carriers, causing epidemics and other disasters.

A reason to worry about is the tendency of growing in the number and damages of forest fires in Bulgaria. In 1992 in the borders of our country, as a result of 600 fires, more than 50,000 dca of forests were destroyed. In 2000 the number of forest fires is more than a thousand, $528808 \mathrm{dca}$ of forests were destroyed. (23)

Fire could occur as a secondary source of damage in case of earthquake, landslides, collapses, huge industrial breakdowns etc. $(33,34,35)$

Fires could be a main factor in time of wars, terrorism, etc. $(7,36)$

The increasing danger of chemical breakdowns with spreading lite dangerous chemical substances in XX century is connected with 4 main reasons: huge fires, different blasts, spreading of chemical substances while working with them, storage or transportation and using of chemical weapons. $(7,37)$

Bulgarian industry produces uses around 500 chemical substances. The most dangerous ones are blast and fire causing and very toxic. (38) According to (39) the consequences of techno gene. Breakdowns depend to a high extend on the quantity of poison spread and the speed of wind. When huge quantities of industrial are released and inappropriate meteorological conditions, atmosphere is polluted and seat of chemical infection occurs - SCI. $(40,41)$

In case of breakdown situation, poison substances are a real danger of disturbing the ecological balance, which threatens life and health of humans. $(37,42,43)$ Industrial breakdowns happen more and they can develop hygiene - epidemiological problems.

S. Lekov and Co. (1990) etc. recommend medical insurance in case of SCI and acute massive intoxication to include not only Fist Aid Help in the region and special toxicological clinic and also strict hygiene control after that. For preserving and precaution of the consequences of possible industrial breakdowns, a main role play hygienic, preservative and preventive health measures. Hygiene - epidemiological problems are second rate. This is a result of the changed conditions of life in the polluted areas. Evacuation and transporting of the ensured and population will contribute for their occurring.

Ch. Nenchev, P. Sulovski (1987), J. Gouxelez (1992) recommend the measures for protection of the population through the earliest phase after a toxic breakdown to include: covering, protection at breathing origins, iodine preventive measures, evacuation, control of air, water, food and hygienic events for cleaning up the polluted areas.

The hygiene - epidemiological problems are not directly connected to the effect of the toxic substances. They could be a result of the bad living conditions, bad feeding because of reducing the immunity of the population, especially for the chronically ill people.

The epidemics are a serious danger for the population of all continents, especially if the agents of the inflection diseases are used intentionally for military and terrorism purposes. In biological laboratories of the ex USSR the agents of very dangerous diseases like small poxes and plague are kept. There are resident types of the page to antibiotics.

The diseases caused by bacteria and viruses have been destroying whole countries and continents through the centuries. In 1940 diseases were the reason for $\mathrm{j}$ of people' deaths. Nowadays the depth rate because of diseases is below 3\% (48) In XXI century what is specific for epidemics is the extremely fast spreading in all countries. In March 2003 people from all over the world were shuttered by the news for the deadly "Asian pneumonia" /TORS/. It started from Hong Kong but spread quickly in 30 countries. At the end of 2005 a serious danger occurred - the virus H5N1 /bird flu/.

According to historical data, biological weapon has been used many times. The achievements of biology through XX century discovered the ability of their using on such a scale which could lead to catastrophic consequences. (49).The modern use of such agents against military contingents and population is a real treat. $(50,51)$

The sources of some very dangerous illnesses are also thought to be biological weapon - anthrax, brucellosis, cholera, pledge, psittacoses, Q - fever, salmonellas, small pox, etc. $(52,53)$ 
According to V. Boneva (2003) this weapon is mainly used in military situations but in the coming century there is a significant risk using biological weapon in terrorists' attacks.

The estimate of the losses of biological weapon mainly depends on the type and qualities of the used agent; the size of the contaminated area; the geographic specifics; density of population; its preliminary preparation and immunization; the availability of individual and collective devices for protection, the sanitary - hygiene conditions of the population and others. (54)

The hygiene - anti epidemical measures are very important in case of using biological weapon. (55)

At the beginning of XXI century the world is facing new challenges in the sphere of security. The tragically events in USA on 11.09.2001, in Moscow on 23.102002, in Istanbul on 15.03 and 20.11.2003, in Kerbala on 27.12.2003, etc changed globally the security of population. The terrorism and organized criminality turned into a first rate anthropogenic treats. $(56,57)$

\section{CONCLUSION}

Disastrous situations, besides their character, size and combination, change factors of environment and effect negatively the population. With most common disasters - earthquakes, floods, landslides, fires. Large industrial breakdowns, epidemics, use of biological weapon etc., curing and evacuation, hygiene - epidemiological problems occur. In crisis situations, the difficult medical situation creates significant problems for healthcare when giving medical help and preventing epidemiological situation. Hygiene - anti epidemiological insurance must be lead in case of floods, epidemics, bioterrorism.

The role and significance of anti epidemiological activities in extreme situations, except for epidemics, are not researched completely.

\section{LITERATURE}

1. WHO, International trail and health. Geneva, WHO, 2000.108

2. Jaschke G., H. Roding. Catastrophi medicine - a new science just a new name. Zeitschrift fur Arztlihe Fortbildung - Jena. 84(22) : 1135-6. 1990.

3. Nechaev E., G. Nazarenko, V. Zhizin.Military medical doctrine and the developmend of the concept of disaster medicine. Voenno-Medicinskii Zhunal. (4): 4-9, 80, 1993 Apr.

4. Abbado, G. Medical structures of casual elemental accidents, VMJ, M, 8, 1990, 28.

5. Leonard R., U. Teitelman. Manmade disasters. CriticalCare Clinics. 7(2) : 293-320, 1991 Apr.

6. Pepe P., V. Kvetan. Field management and critical care in mass disasters. Critical care Clinics. 7(2) : 401-20, 1991 Apr.

7. Popzaharieva V, Medicine of catastrophes, edition Knowledge, St. Zagora, 1995.
8. Roth P., A. Vogel, G. Key, D. Hall, C. Stockhoff. The St. croix disaster and the National Disaster Medical System. Annals of Emergency Medicine, 20(4) : 391-5, 1991 Apr.

9. Chakarova, P., Il. Michaylova and authors, Бедствени ситуации, възникнали през 1999 г. криещи риск за околната среда, VII Нац. Конгрес по хигиена, Резюмета, С, 2-4.XI, 2000.

10. Hristiskov L., B. rangelov, E. Spasov, N. Dotzev. Organized and individual actions at heavy earthquake. VI, C., 1989.

11. Hristiskov L., Earthquakes - danger and реацтион. Ед."М \&M", C, 2000.

12. Ishii N., S. Nakayama. Emergency medical care following the great Hanshin-Awaji earthquake: practices and proposals. Kobe-J-Med-Sci. 1996 Jun; 42(3): 173-86.

13. Filipov, D., St. Krusev, L. Lazarova, Geographical prerequisites for arising of disastrous situations in Republic of Bul;garia. IV national congress medical geography, Thesis, 1991, Varna, 88-89

14. Mikhaylova, I1., R. Chakarova and authors., The role of Bulgarian formations at liquidation of earthquakes in Turkey in 1999 г., Scientific reports on medical geography, C., 2001.

15. Nikolov, N., G. Tachev, N. Radev, V. Angelov. Civil defense at present stage - real possibilities and problems.,II Scintific conference "medicine of catastrophes - analoque of military trauma", 20-22.X. C.1993.

16. Botev, E., I. Aleksandrova, The seismic noose around us, pilot copy VIK, 1992, 4-5

17. Mikhaylova, I1., R. Chakarova, St. Krusev, D. Filipov, Territory analysy of medical consequences from disastrous in Bulgaria. IV National congress on medical geography, Thesis, 1991, Varna, 89-90

18. Bolt, B., W. Horn, G. Macdonald, R. Scott. Geologial Hazard. "Springer - Verlag", 1977.

19. Mikhaylova, I1., Contemporary tendencies in the organization of medical aid at disastrous situations, Hygiene and healthcare, 1995, 6, 3 - 4.

20. Nakamura H. Overview of the Hanshin-awaji earthquake disaster. Acta-Pediatr-Jpn. 1995 dec; 37(6): 713

21. Scheidegger, A. Physical Aspects of Natural Catastrophes. ESPC, 1995

22. Novikov, Y., V. Sobishek, Y. Nekovarzh. Space ecological monitoring, Bratislava, 1986.

23. Krusev, St., D. Filipov, G. Chalrakchiev, Medical geographical assessment of crisis situations, Scientific reports on medical geography, Sofia 2001,59-63

24. Raychev, N., M. Deneva, I. Denev, Attempt for epidemiological prognosis under conditions of disastours /floods/, IV National congress on medical geography, Thesis, 1991, Varna, 89 - 91.

25. Dramova, V., Drinkabale wateer as a factor for bringing of pathogenic agents at man, MA, Referat informational buletin, medical sanitary protection, 1, 1985, 13-16.

26. Payment, P., F. Eduardo et all., Appl. And Environ., Microbiol., 1991, 57, № 4, 945-948.

27. Yustinianova, B. and authors., Assesment of sanitary micro biological indexes of drinkable water and the 
acute intestine sick rate in Varna, III Scintific conference." Ecology, economics and living middle of Black Sea region", B., 3-4 June 1993, 382-388.

28. Mladenova, K., The landslides continue to creep, VIK, 1994, 3, 7.

29. Stakev, M., T. Chitarlieva, Can we control the landslides, VIK, 3, 1999.

30. Mardirosyan, G. From the Space against the ecological catastrophes. Ed. Of BAS, Sofia, 1993.

31. Mikhaylov, Ya. The catastrophes in the world. M. BRC, 6, Sofia, 1993.

32. Trantner, Sv., St. Lennquist, Fery disaster in Denmark, Managament of Public, Healt case of disaster, Nottwil, Schweizland, 1997.

33. Valkov, Tz., The carelessness "food" for the fire, CP, 1989,7,18-19

34. Ivashkin, V. T. And authors. Organization of special and therapeutic help for the victims in Armenia. VMJ., 1990,3

35. Nakamori Y., H. Tanaka, J. Oda, Y. Kuwagata, T. Matsuoka, T. Yoshika. Burn injuries in the 1995 hanshin-Awaji earthquake. Burns. 1997 Jun; 23(4): 319-22.

36. Gambihler, R., Metro-Katastrophe vom 28.10.1995 in Barn Aserbeischan, Mottwil, 1997

37. Monov. A., T. Tashev. Toxicological models. "Enthropy", S. 1996, 10-14

38. Chuturkova, R., M. tosheva, Research of combined action of the atmosphere pollution on the sick risk of population, living in an industrial area, Scientific session of MU Pleven, 1992, Co Summarries, 209 - 211.

39. Gostushin, A., Enciclopedia of extreme situations, M., 1994.

40. Chakarova, R., Researches of some industrial plants in the country potentially dangerous for arising of AID from industrial poisons in peaceful time and in conditions of contemporary war, Disertation, Sofia, 1985.

41. Glikman Theodor S, Golding Dominic, Recent trends in major natural disasters and industriel accidents, Earth Sei Programme News lett. Common wealth Sei Connc, 1993, 11-15, jan-febr.

42. Dobrev, I. V. Kostova, Traumas and poisoning among children - medical social problems, Social medecin, 3-4, 1994. 43.Rosen, I., et all. - Toxicol. Apl. Pharmacol, 145, 1997, 381-387.
44. Tarasenko, V. M., V. M. Polyakov, Some problems for people protection at, accidents,c atastrophes and disastours, problems safety at accidents, VINITY, 1992, 5, 20-31

45. Nechev, Hr., P. Salovski. Protection at radiology dangert. MF, C., 1987.

46. Gouxalez, A. J. Fundamental principles of protection and safety for nuclear prower. IAEA Bulletin, 34, 1992, $\mathrm{N}: 2$, 47.Gacheva, N. and authors., Acute inflectous diseases in Bulgaria, 1996, informational journal, National center of infectious and parasitic diseases, C. 1997, бp.3, 22-23

48. Petrov P. and authors., Epidemiological characteristique of imported parasitic diseases in Bulgaria in 1990 - 1999, IV national congress on medical geography, Thesis, Sofia, X, 2000, 94 - 96.

49. Mitov, D., N. Bogdanov, Contemporary bio terrorism - a real danger, Co. Thesis, VI congress on medical geography, C.,2000.

50. Boneva, V. V. Slavova, L. Pekova, V. Popzaharieva, Biological weapon - risk factors for applying, XIII Assambley of IMAB, Varna 28-31.V.2003.

51. NATO Handbook, Office of Information and Press, 1110 Brussels, 2001

52. Burrows, W. D. et S. Renuer. Biologikal watare agents as threots to potable water. Environ. Health Perspekt. 107. 1999, 12, 975-985.

53. Dragnev, V., V. Konov, Aspects of medical insurance at arising of focus of biological pollution, Anniversary conference of MF of Thracian University, St. Zagora, X, 2002.

54. Cohen, R. E., Disaster workers, Mental health services in Disasters: Instructors guide (PAHO - OPS, 2000, 174p.)

55. Angelov, L. Epidemiology of infectious deseases, MI, Vasil Petrov, VAP, Plovdiv, 2001.

56. Jannier, D., Attentats daus le metro Parisien-Comporation entre un acte de terrorisme chimique, Samn, Paris, 1995

57. Takiquchi, M., Terrorism by Sarin happened in the subway in kokgo 1995Catasttrophe Disastec,Nottwil,Luzern, 1997 